\title{
The Reenchantment of Death: Near-Death, Death Awareness, and the New Age
}

\author{
Raymond L. M. Lee, Ph.D. \\ Department of Anthropology \& Sociology, \\ University of Malaya
}

\begin{abstract}
Since the first publication on the near-death phenomenon appeared about 30 years ago, many theories have been offered to explain its manifestation and meaning in relation to the question of the survival of consciousness after death. However, the contextual question regarding the receptivity of the near-death phenomenon has not been adequately answered. This question concerns the social conditions that have popularized the discourse of the near-death experience. These conditions can be identified as the reenchantment of the world within the context of the New Age, the emergence of death awareness in a rapidly aging population, and the renewal of faith within the context of religious revivalism.
\end{abstract}

KEY WORDS: near-death experience; death awareness; reenchantment; New Age; religious worldviews

In the last 30 years, the near-death phenomenon has enlivened our imagination of the afterlife. Research on the near-death experience (NDE) pioneered by Raymond Moody (1975, 1977), Kenneth Ring $(1980,1984)$ and Michael Sabom $(1982,1998)$ has received much public attention. Various theories have been offered to explain its manifestation and meaning. A comprehensive review of these theories can be found in a recent review by Mark Fox (2003). Most of the near-death

Raymond L. M. Lee, Ph.D., is in the Department of Anthropology and Sociology at the University of Malaya. Reprint requests should be addressed to Dr. Lee at the Department of Anthropology and Sociology, University of Malaya, 50603 Kuala Lumpur, Malaysia; e-mail: raymond@um.edu.my. 
literature deals with the phenomenology rather than the sociology of the NDE. Although some writings on the NDE, such as those by Carol Zaleski (1987), Ioan Couliano (1991), and Allan Kellehear (1996), attempt to frame it within a historical and crosscultural perspective, these writings were more concerned with the comparative aspects of the NDE to demonstrate that the NDE is not exclusively a $20^{\text {th }}$ century or Western phenomenon. The question of why the NDE came into public view in the closing decades of the $20^{\text {th }}$ century has not been adequately answered.

What is it about this period that has nurtured public awareness and receptivity of the NDE? Such a question suggests that the social context in which discourse of the NDE emerged is critical to an understanding of the social recognition given to the meaning of the near-death phenomenon. In other words, the contemporary identification of the NDE cannot be divorced from the wider social context in which such interest arose in the first place. Kellehear (1996) addressed the changes in death attitudes and development of medical technology that have contributed to the public receptivity of the NDE. But there are other social factors that need to be considered.

The aim of this article is to identify the social conditions that have made possible the appearance and celebration of the NDE and its reification through an expanding literature, ongoing research, and public controversy. I adopt three approaches to discuss the conditions underlying the discourse of the NDE. First, I discuss the process of reenchantment. This refers to a process of reactivating thoughts, ideas, and beliefs that had become moribund or untenable with the rise of the scientific worldview. The occurrence of reenchantment in the New Age is relevant for understanding how the NDE fits into a new spiritual paradigm. Second, the emergence of death awareness has contributed to an increased interest in the meaning of death and the means for overcoming the fear of death. The NDE represents a challenge to the nihilism that underlies the universal terror of death. Third, debate about the nature of the NDE has disclosed a universalistic versus a particularistic interpretation of the NDE within the context of religious revivalism during the closing decades of the $20^{\text {th }}$ century. These opposing views of the NDE suggest that the NDE is not necessarily an objective phenomenon. Rather, they are couched within a sharply divided religious environment that promotes disparate views of the meaning of the NDE. 


\section{The New Age and Reenchantment}

Reenchantment is the reverse of disenchantment, the process of disentangling science from magical worldviews. Max Weber (1946), the eminent German sociologist, spoke of disenchantment of the world as the reduction of human perceptions and actions to regulated and predictable patterns that left no room for mystical ruminations and supernatural explanations. The emergence of the scientific worldview constituted the basis from which worldly progress was construed as the overcoming of the magical and enchanted framework of reality. Disenchantment offered a new outlook for the empirical verification of everyday reality, freeing reason to become the driving force of world development and mastery. By closing off the traditions that informed an enchanted worldview and transforming them into rationalized structures of belief and action, a modernized sense of reality came into being to address all conditions of plausibility as resting on the primacy of falsifiable proof. Beliefs in spirits, souls, and arcane forces became marginalized, relegated to the anachronistic realms of religion and superstition.

Scholars using Weber's ideas have noted that disenchantment was not separate from the process of secularization in which institutionalized religion declined in influence (Bruce, 2002). Religious beliefs about the world and the afterlife did not necessarily become otiose, but they could no longer compete with the rapid growth of scientific and technological outlooks. Disenchantment offered a more objective and lucrative approach to the manipulation of reality, compared with religious enchantment that could only offer at best the allurement of faith. Secularization became indispensable to societal development, paralleled by disenchantment that replaced the intangibility of the spirit world with the rationality of the ordinary world.

A consequence of disenchantment was the increasing identification of predictability with bureaucracy and routinization. It was reason that was now animating the structures of bureaucracy. Originally conceived as the key to world mastery, reason now came to circumvent creativity through the disenchanted ethos of work, management, and social order. Yet, the sense of creativity was never completely extinguished by disenchantment. It lived on in the Romantic and neoRomantic currents of Western society, constituting a source for the reenchantment of the self (Lee, 2003). 
Reenchantment marks the outer limits of disenchantment. It is a process that reintroduces and revives beliefs and knowledge that became obfuscated by the conventions of science, technology, and bureaucracy. This does not necessarily imply the end of disenchantment. Rather, the structures of disenchantment are no longer the privileged disseminators of truth. For the better part of the $20^{\text {th }}$ century, these structures determined the contours of modern reality. Modern societies of the $20^{\text {th }}$ century were indisputably disenchanted in terms of organization and cultural belief. Yet, throughout the $20^{\text {th }}$ century, and more noticeably in the latter half of that century, cultural and religious movements in the West made significant impact in challenging the conventionalities of disenchantment (Robbins, 1988; Zellner, 1994). Informed by Romantic ideals, these movements addressed the aridity and inadequacies of the disenchanted mind. They were not critical of science and technology in themselves, but gave more emphasis to ideas and beliefs outside the scientific worldview as part of the bigger picture of reality. The activities of these movements represented a "major counterprocess of modernity" (Tiryakian, 1992, p. 86).

It is in this counterprocess that we see the germ of reenchantment. Unlike disenchantment, which contributed to the fragmentation of knowledge as a feature of modernity, this counterprocess attempts to reorganize the meaning of knowledge through an appeal to esotericism (Lee and Ackerman, 2002). Knowledge is no longer treated as mutually exclusive segments of the same reality, but as varying dimensions of a generally unified state of existence. In other words, it is unnecessary to isolate knowledge that is not within the purview of conventional science and technology. Although such knowledge is considered esoteric insofar as it does not conform to scientific conventions, it is nevertheless regarded as vital to a deeper understanding of the nature of reality. Reenchantment is, therefore, not merely a component of this counterprocess that attempts to rejuvenate a holistic approach to knowledge. It is also a process of actualizing esotericism in everyday life, bringing into practice the beliefs that science had jettisoned as superstition. As esotericism pervades everyday thought and behavior, it comes to be treated as less threatening to conventional knowledge and routines. Over the course of time, it is likely to become normalized as an acceptable option to the meaning of existence.

The context in which reenchantment is occurring has been referred to as the New Age (Heelas, 1996; York, 1995). The New Age is not considered "new" in the sense of innovative discoveries in the 
manipulation of reality, but in terms of replumbing the depths of human potential for a more complete understanding of reality. In this regard, the New Age is treated more like a cultural movement, rather than a specific era of discovery, that attempts to overcome barriers to an inner understanding of human experiences. New Age exponents are not necessarily hostile to empirical knowledge based on the criteria of the external world, but they tend to construe such knowledge as limited and a demonstration of the impoverished human mind. Inner understanding allegedly provides a wider, holistic perspective that takes the external world as a manifestation of deeper principles not readily accessible to our ordinary senses and perceptions. The external world, according to this perspective, is not a given, and therefore cannot be taken for granted. It merely represents a construction of our minds that unwittingly veils a more subtle reality fundamental to the human spirit. Thus, the New Age is concerned with the committed exploration of our inner self in order to recover the hidden spirituality common to all human beings. It is a term closely associated with people "who maintain that inner spirituality-embedded within the self and the natural order as a whole-serves as the key to moving from all that is wrong with life to all that is right" (Heelas, 1996, p. 16).

The New Age is not in itself a closely knit, cohesive movement. It is a disparate movement with many strands of spiritual thought and activity that are traceable to $19^{\text {th }}$ century Romanticism and the counterculture of the $1960 \mathrm{~s}$. Despite this diversity, spiritual seekers in the New Age are bound by the belief in the authenticity of the inner voice. It is this voice that guides our decisions and choices in everyday life. If untapped, it becomes dormant, seemingly inaccessible to ordinary people, whose lives are considered banal and inauthentic. Paul Heelas (1996) referred to this voice as the Selfethic, or the source of guidance that lies deep within, transcending the boundaries imposed by the ego. Within the framework of the Self-ethic, meaning is no longer subjected to the conventions of the disenchanted world, but realized as the possibilities of inner knowledge finding expression through the processes of reenchantment. The self intuitively discovers the esoteric dimensions of its own potential simply by looking within for the freedom denied by the structures of disenchantment.

How does the NDE fit into this new spiritual paradigm that promotes the power of the inner self? Firstly, the NDE is not an experience that can be actively sought after, like many types of 
New Age activities. The NDE is essentially an involuntary process of entering an altered state of consciousness following clinical death. Most people who report NDEs are not likely to be experimenting with dying in order to test the survival of consciousness after death. NDErs are typically people who were not prepared for death, but died momentarily and later were resuscitated. It is only during this brief period of clinical death that they came to experience traveling to another realm to meet deceased relatives and friends and to encounter an extraordinary light. Such experiences tend to provide NDErs with a sense of self-empowerment not derived from their ordinary lives.

Secondly, it is the esotericism of the New Age that facilitates the translation of this sense of empowerment into a candid acceptance of new realities. It is as though the veil of disenchantment had been lifted, to reveal other dimensions of existence hidden deep within the NDErs' consciousness. Like New Age seekers, NDErs' discovery of their inner power to access alternative realities is a form of selftransformation within a larger framework of spiritual realization. They no longer see the world through the prism of disenchantment, but are able to reinterpret their lives in terms of broader spiritual principles. These principles underlie the inner experiences of both the NDEr and the New Age seeker.

The parallels between the NDEr and the New Age seeker do not necessarily suggest that the NDEr is actually a type of New Age seeker. Unlike the New Age seeker who actively explores alternatives to a life of disenchantment, the NDEr is generally an explorer of inner space by serendipity. Because of an unanticipated encounter with other realms of existence through dying, the NDEr comes to appreciate alternative meanings to the present life that previously were unknown or did not appeal to him or her. It is a process of selftransformation in the NDEr that connects him or her to the New Age understanding of subtler realities.

Thirdly, ongoing reenchantment in contemporary society has opened an interstice in the structures of disenchantment that can foster communication between NDErs and near-death researchers. Such communication has led to greater public awareness of the neardeath phenomenon as a plausible area of investigation and personal reflection. The pioneers of near-death research were physicians and psychologists whose training within the structures of disenchantment did not form an obstacle to their acceptance of the NDE as a phenomenon worth studying. It is likely that near-death research 
has attained a level of legitimacy because of the professional standing of these pioneers. In other words, the legitimacy for near-death research reflects and feeds into the processes of reenchantment in contemporary society. Fascination with the NDE does not imply that near-death researchers are by definition New Age seekers, but that they are not immune to the effects of reenchantment. Without reenchantment, it is unlikely that the NDE would have made such an impact on scientific professionals nurtured within the structures of disenchantment. The NDE would have been dismissed simply as the deliriums or hysterical visions of resuscitated patients.

The relationship between the NDE, the New Age, and reenchantment suggests the importance of contextual developments in understanding how unusual phenomena, initially considered absurd, come to be defined as something acceptable for further inquiry. Neardeath research has attained legitimacy not because the structures of disenchantment are no longer hegemonic, but because reenchantment is providing a context for addressing all the voids left unfulfilled by the theory and method of the disenchanted worldview. The power of the inner self is one of these voids that have not been satisfactorily addressed within the framework of disenchantment. Ongoing reenchantment has provided a vehicle for connecting the sense of inner power with the NDE, in the context of emerging awareness of death and dying.

\section{The Emergence of Death Awareness}

The conjecture that the death taboo has replaced the sex taboo in modern society appears to have been nullified by the emergence of death awareness in the last few decades. Death awareness refers to sensitivity toward philosophical, ethical, and religious issues concerning human mortality. Awareness of mortality is not in itself a new development of human reflexivity, but it is the intensity of this awareness that is changing attitudes toward the meaning of death. It is these changing attitudes that have played an important role in increasing public receptivity to the NDE.

What factors have contributed to the intensification of death awareness? Firstly, the terror of death has, in its own paradoxical way, transformed the denial of death into a confrontation with death. It is as though people fear death in order to come to terms with it. Far from alienating us from our mortality, the dread of death is 
inadvertently opening up new ways for us to inquire into our fate to die. The appearance of two books about three decades ago signaled this transformation. One was a book on death and dying by a physician, Elisabeth Kübler-Ross (1969). The other was a book on the denial of death by an anthropologist, Ernest Becker (1973). As a physician who worked with dying patients, Kübler-Ross addressed dying as a five-stage process that included denial, anger, bargaining, depression and acceptance. By identifying these stages of emotional turmoil in dying, it was possible to work with dying patients more effectively. Becker, on the other hand, was more concerned with the anxiety of death as the basis of all human drives. His work was theoretically a neoFreudian confrontation with the existential problem of dying. Together, these two books brought to public attention the modern fear of death and its consequences. They penetrated the death taboo to transform it into a method of knowing death.

The impact of these books cannot be separated from the growth of the hospice movement and the increasing concern with care for the dying. The modern concern with death is not about the quest for immortality, but about the limits of the physical self, strategies for coping with dying, and dealing with the pathos of death. It is a concern that is deeply rooted in a pragmatic attitude toward the world. Modern physicians, hospice workers, and care providers grapple with mortality in the most practical manner. They attempt to give back to dying patients their dignity and identity. By providing physical comfort and counseling to the dying, these professionals attempt to instill hope in an experience governed by fear. It is a hope that reinforces the patient's identity. This identity is affirmed by an acceptance of death as the final exit, a culmination of experiences that have enriched the patient's journey through life. Dying patients are taught to let go without losing their sense of self. A highly informative review of these developments in death and dying can be found in Tony Walter's book, The Revival of Death (1994).

These attempts to understand death and dying were embedded largely within a disenchanted worldview, and did not consider the possibility of death as a doorway to alternative realities. Dealing with the fear of death within a disenchanted worldview only reduced the sense of desperation in coping with the termination of life. Death could not be stopped, but at least people could come to accept it unconditionally if they no longer feared it. At the same time, being aware of the inevitability of dying has made possible a greater 
willingness to inquire into the nature of death itself and the possibility of consciousness surviving death. In this context of death awareness, the NDE would not be considered an egregious outcome of unscientific thinking, but a profound phenomenon that might revolutionize the way most people think about death and dying.

Secondly, the growing number of older people in the world population suggests a demographic dimension to the intensification of death awareness. According to a recent World Health Organization report (http://www.who.int/hpr/ageing/ActiveAgeingPolicyFrame.pdf), across the world the proportion of people aged 60 and above is growing faster than any other age group. The population of people over the age of 60 is expected to reach 1.2 billion in 2025 . In developed countries such as the United States, the number of people aged 60 and above totaled 46.9 million, or about 16 percent of the population, in 2002 . In the United Kingdom, people in the 60 and above age group comprised 20.8 percent of the population in 2002 .

It is inevitable that as people reach middle and late age, their attention will shift to practical concerns that are related to the anticipation of retirement. One of these concerns relates to preparation for their eventual demise, such as writing of wills, disposal of property, and so on. It is during this period of gradual withdrawal from work and career that most people would feel an inclination to reflect on their exit from the world. As more people, especially in developed countries, live longer and healthier lives, they tend to have more time to dwell on the meaning of their lives in the context of imminent death. Questions related to dying and the afterlife become more meaningful at this stage in life. The larger number of such people in the world over the last few decades implies that these questions are not confined to a small minority, but have become central to the lives of a significant segment of the world population. Such a trend is likely to be more significant in developed countries, especially in the West, where advanced knowledge in medicine and health care is prolonging the lives of many elderly people.

Given this demographic profile, it should not be surprising that the NDE has become a preoccupation of many people in societies with aging populations, especially those in the West. Uncertain about the fate of their consciousness, many middle-aged and elderly people would want to know whether there is life after death. The NDE provides a special discourse for probing a question that is foremost in the minds of people in their twilight years. In populations with many such people, the NDE would undoubtedly be considered a phenomenon 
not to be dismissed lightly, because it addresses their concern with the possibility of life after death.

Thirdly, the process of reenchantment cannot but impact on the growth of death awareness, since it is a process that offers an alternative worldview that extends beyond the meaning of life in the here-and-now. As discussed above, reenchantment is a process that rejuvenates esoteric worldviews, and it can therefore blunt the nihilistic view of death by addressing death as a bridge between different levels of consciousness. The reenchanted view of death eschews the vision of nothingness, because it is focused on the empowerment of consciousness in any state of existence. It means that the power of consciousness is a power of transformation that regenerates movement and action. Thus, death is not necessarily the end of life, but its transformation, "a change of scenery."

Death awareness developing within a reenchanted worldview is likely to result in attempts to cultivate knowledge for entering new states of consciousness upon dying. These attempts offer practitioners of dying techniques the means to manipulate consciousness within a framework of esoteric knowledge. Discussion of some of these techniques can be found in manuals of instruction for dying, such as the one written by Anya Foos-Graber (1989). Basically, these manuals are derived from the principles of Indian metaphysics concerning the movement of energy and consciousness in the subtle body. The techniques are based on the belief in the existence of such a body and its components such as the central channel (sushumna) and the energy wheels (chakras). Instructions in these manuals focus on visualizing and manipulating the movement of energy and consciousness along the central channel and in the energy wheels as the dying person prepares to exit his or her physical body.

Without a reenchanted view of death, the NDE would likely be treated as a new myth invented by seekers of immortality. However, the process of reenchantment is not about the fixation on the search for immortality. The question of seeking immortality is not addressed, because reenchantment is concerned with the empowerment of consciousness at different levels of reality. Techniques of dying are therefore not special methods for attaining immortality, but for realizing new levels of postphysical reality. Within this context of death awareness, the NDE would be considered credible because it confirms the movement of consciousness between different levels of reality. In a popular book on the Tibetan approach to death and dying, Sogyal Rinpoche (1993) addressed the NDE as providing a glimpse 
into other levels of postphysical reality. Ostensibly, he recognized the NDE as special phenomenon within a reenchanted view of death, but without implicating it in the debate on the quest for immortality.

The relationship between the emergence of death awareness and the discourse on the NDE suggests that the recent public engagement with issues of death and dying was critical to the development of a favorable reception of the NDE as a phenomenon in its own right. This reception of the NDE must also be considered within the context of a religious trend emphasizing the renewal of spiritual beliefs and missionary action. Different interpretations of the NDE within this context of religious revivalism have polarized the meaning of death and the afterlife.

\section{Religious Revivalism and Interpretation}

The discourse of the NDE occurred during a period of fervent revivalism in the world religions. The causes and consequences of this revivalism have been documented and discussed at length in other works (Stark and Bainbridge, 1986). What concerns us here is the significance of this revivalism for the reception and interpretation of the NDE. The NDE is in itself not considered a religious phenomenon, but within the context of religious resurgence it can come to take on religious meanings. In other words, interpretations of the NDE are not devoid of religious influences and can come to be marshaled as evidence for particular religious theories of human existence.

One of the important features of religious revivalism is the renewal of faith. When religious beliefs and actions are reactivated and receive inordinate attention, the question of faith attains greater value in relation to the way people interpret the meaning of their lives as conditioned by grace or divine influences. The mundane world is no longer taken for granted, but perceived as an inherent outcome of a grander scheme, to which only faith can penetrate and take hold. The renewal of faith constitutes a fervent exercise in redoubling one's belief in the forces of the unseen world that act upon everyday reality. Within the religious system to which a person belongs, this belief not only becomes stronger, but also contributes to the continuation and even possibly the transformation of the entire system or part of it.

In the case of the $\mathrm{NDE}$, the experience itself is generally not considered religious, because it lacks the motivation that is attributed 
to salvationary actions. People who report NDEs do not typically place themselves in a perilous position to achieve salvationary goals. The average NDEr is not impelled by religious beliefs to seek death as a means to reach God. Only in accounts of their experiences after the fact are religious references found. Thus, the extraordinary light in their encounters may be interpreted as God, Jesus, or some other religious figure. It is important to note the point made by Fox (2003) that the accounts given by NDErs share structural similarities with testimonies provided by religious experiencers and converts. The implication here is that NDErs, like other religious experiencers, are susceptible to outside influences that shape and modify their accounts. Within the context of religious revivalism, their conceptualization of the NDE can come to take on specific religious meanings that signify a renewal of faith.

Sabom, one of the pioneers of near-death research, confessed that since the publication of his first book on NDEs his "love of Scripture has grown" and his "walk with the Lord has deepened" (1998, pp. 193194). Claiming "deeper spiritual maturity," he could now reconsider the Biblical meaning of the NDE. Quoting extensively from the Bible, Sabom surmised that the NDE was not an actual experience of the afterlife, since the dead could not return to life without the rare intervention of divine forces. The NDEr was not such a reanimated person. Yet he noted that many NDErs became convinced of the reality of life after death, and that the NDE promoted belief in certain Biblical principles. From his Christian perspective, he concluded that the NDE was not anything more than a powerful spiritual experience that produced a deepened belief in the existence and universal laws of God (Sabom, 1998).

Although Sabom himself is not a near-death experiencer, his interpretation of the NDE from the perspective of a committed Christian took a particularistic approach that rejected the NDE as an inexorable account of the afterlife, but viewed it as a special encounter that renewed the faith of the experiencers. The accounts given by NDErs in his study provided specific material from which he adduced a religious dimension that was revelational and stressed the renewal of the Christian message. Within the context of religious revivalism, Sabom's interpretation of the NDE underscored the meaning of a momentous experience as something embedded in the rediscovery of Christian truth. This truth is not found in the NDE itself, but in the way the NDE comes to be seen as representing God's revelation in the wider Christian community. 
Part of Sabom's conclusion was used to rebut the finding by Ring (1984) that the NDE tended to redirect people toward a more universalistic spiritualism. Unlike Sabom, who found his subjects to be more committed Christians after their NDEs, Ring reported that the NDErs in his study expressed a more ecumenical attitude:

It is precisely this ecumenical orientation that must closely represent the core of NDErs' own spiritual perspective. In a sense, their embrace of Eastern religion is not so much a substitution of new doctrines for old as it is an endorsement of the ecumenical spirit of Eastern world views. Indeed, the strongest evidence of NDErs' universalistically spiritual orientation and in many ways the culmination of the qualities already discussed is their belief in the underlying unity of all religions and their desire for a universal religious faith that will transcend the historical divisiveness of the world's great religions. (1984, p. 162)

Ring's interpretation of the NDErs' spiritual transformation has a familiar ring that connects to the work done on the growth of religious movements in America as influenced by Eastern and nonChristian religions (Ellwood, 1979). The influence of these religions in American society in the latter half of the $20^{\text {th }}$ century undermined traditional patterns of Christian belief and commitment. Some of these religions were monistic, some polytheistic, and some philosophically nontheistic, as in the case of Buddhism. Instead of stressing a personal relationship between the devotee and God or Jesus Christ, many of these "new" religions promoted a holistic approach to the cultivation of an inner self that did not conflict with nature or elements of the wider environment. They emphasized meditation as a means to calming the mind in order to arrive at the meaning of truth (Naranjo and Ornstein, 1971). These changes in religious attitudes coincided with the increasing challenge that developed against the structures of disenchantment, first by the counterculture of the $1960 \mathrm{~s}$ and later by the New Age movement. In this context of religious resurgence, Christianity also underwent different currents of revivalist activity (Kepel, 1994), and some Christians came to define the New Age movement as a threat to their mission (Groothuis, 1986). It is therefore not surprising that Ring's ecumenical interpretation of the NDE, which is not antithetical to the ethos of the New Age movement, has been challenged by the more fervent Christian outlook exemplified by Sabom.

The meaning of the NDE in the context of religious revivalism cannot be divorced from the explicit or implicit interests associated 
with the renewal of faith in any organized religion or religious movement. An understanding of this context suggests that it would be naive to assume the interpretation of the NDE to be an actual objective account of extraordinary events. Although the NDE constitutes a phenomenon in its own right, it is the cultural and religious filter through which it passes that transforms it into a dependent variable. Thus, in another cultural context in which shamanism is highly valued, it is likely that the meaning of the NDE would be taken as a symbol of a special calling.

\section{Conclusion}

The NDE has held public attention and fascinated researchers and lay people alike in the last 30 years or so. Its discovery and emergence as a special phenomenon must be treated not as something selforiginating, but as an outcome of contextual developments affecting social attitudes and cultural perceptions. It is chiefly the reenchantment of society that has contributed to a more receptive attitude toward reports of unusual experiences. Changes in popular and scientific thinking, influenced by challenges to the paradigm of disenchantment, have opened the way for the discourse of the NDE. Yet, this discourse has revealed a conflict between universalistic and particularistic interpretations, centering on the question of whether NDErs embrace a more cosmic or specifically religious outlook. Embedded in certain religious trends in society, these interpretations suggest that the NDE cannot be separated from the values that human beings attribute to their experiences. Nevertheless, the growth of death awareness and New Age thinking has provided a niche for the NDE to be researched and discussed for some time to come. These developments have made it possible for us to reconsider the meaning of death without being constrained by the old taboos of disenchantment.

\section{References}

Becker, E. (1973). The denial of death. New York, NY: Free Press.

Bruce, S. (2002). God is dead: Secularization in the West. Oxford, England: Blackwell.

Couliano, I. P. (1991). Out of this world: Other-worldly journeys from Gilgamesh to Albert Einstein. Boston, MA: Shambhala.

Ellwood, R. S. (1979) Alternative altars: Unconventional and Eastern spiritualities in America. Chicago, IL: University of Chicago Press. 
Foos-Graber, A. (1989). Deathing: An intelligent alternative for the final moments of life. York Beach, ME: Nicolas-Hays,

Fox, M. (2003). Religion, spirituality and the near-death experience. London, England: Routledge.

Groothuis, D. (1986). The New Age movement. Downers Grove, IL: Intervarsity Press.

Heelas, P. (1996). The New Age movement: The celebration of the self and the sacralization of modernity. Oxford, England: Blackwell.

Kellehear, A. (1996). Experiences near death: Beyond medicine and religion. New York, NY: Oxford University Press.

Kepel, G. (1994). The revenge of God: The resurgence of Islam, Christianity, and Judaism in the modern world. University Park, PA: Pennsylvania State University Press.

Kübler-Ross, E. (1969). On death and dying. New York, NY: Collier/Macmillan.

Lee, R. L. M. (2003). The reenchantment of the self: Western spirituality, Asian materialism. Journal of Contemporary Religion, 18, 351-367.

Lee, R. L. M., and Ackerman, S. E. (2002). The challenge of religion after modernity: Beyond enchantment. Aldershot, England: Ashgate.

Moody, R. A. (1975). Life after life. Covington, GA: Mockingbird Books.

Moody, R. A. (1977). Reflections on life after life. St. Simon's Island, GA: Mockingbird Books.

Naranjo, C., and Ornstein, M. (1971). On the psychology of meditation. New York. NY: Viking.

Ring, K. (1980). Life at death: A scientific investigation of the near-death experience. New York, NY: Coward, McCann and Geoghegan.

Ring, K. (1984). Heading toward omega: In search of the meaning of the near-death experience. New York, NY: Morrow.

Rinpoche, S. (1993). The Tibetan book of living and dying. San Francisco, CA: HarperSanFrancisco.

Robbins, T. (1988). Cults, converts and charisma: The sociology of new religious movements. Newbury Park, CA: Sage.

Sabom, M. B. (1982). Recollections of death: A medical investigation. New York, NY: Harper and Row.

Sabom, M. B. (1998). Light and death: One doctor's fascinating account of near-death experiences. Grand Rapids, MI: Zondervan.

Stark, R., and Bainbridge, W. S. (1986). The future of religion: Secularization, revival, and cult formation. Berkeley, CA: University of California Press.

Tiryakian, E. (1992). Dialectics of modernity: Reenchantment and dedifferentiation as counterprocesses. In H. Haferkamp and N. J. Smelser (eds.), Social change and modernity (pp. 78-94). Berkeley, CA: University of California Press.

Walter, T. (1994). The revival of death. London, England: Routledge.

Weber, M. (1946). From Max Weber: Essays in sociology. London, England: Oxford University Press.

York, M. (1995). The emerging network: A sociology of the New Age and neo-pagan movements. Lanham, MD: Rowman and Littlefield.

Zaleski, C. (1986). Otherworld journeys: Accounts of near-death experience in medieval and modern times. New York, NY: Oxford University Press.

Zellner, W. W. (1994). Countercultures: A sociological analysis. New York, NY: St. Martin's Press. 